\title{
Karakteristik Proses Metakognisi Mahasiswa dalam Menyelesaikan Masalah Kalkulus
}

\author{
Dwi Purnomo \\ Program Studi Pendidikan Matematika IKIP Budi Utomo Malang \\ Jalan Citandui 46 Malang \\ e-mail: dwi2purnomo@yahoo.co.id
}

\begin{abstract}
The study aims at analyzing and describing characteristics of the students' meta cognition process in completing calculus about function limit application to determine maximum and minimum scores through awareness, evaluation, and regulation as the components. The study involves 23 students of mathematic education department having took differential calculus as the subject. The data of the research were work result, think aloud recording, observation sheet, questionnaire response, and interview manuscript. The group work result were categorized into highly, medium, and low capable subjects. The data collected were then analyzed using comparative method of Glaser and Strauss. Based on the data analysis, it was found that characteristics of the students' meta cognition process were categorized into highly, medium, and low capable subjects with awareness, evaluation, and regulation indicators the process of which occurred completely, respectively, completely irrespectively, and irrespectively
\end{abstract}

Keywords: metacognition, awareness, evaluation, calculus

Matematika sebagai bagian dari proses pembelajaran di kelas pada hakikatnya terdiri dari objek langsung dan tidak langsung. Gagne (Soedjadi, 2000; Hudojo, 2008) menyatakan, objek langsung matematika berhubungan dengan fakta, konsep, operasi, dan prinsip. Fakta merupakan konvensi atau kesepakatan yang digunakan untuk memperlancar pembicaraan dalam matematika, seperti lambang, notasi, atau simbol. Simbol "4" sudah dipahami sebagai bilangan "empat". Jika disajikan " 4 " orang sudah menangkap maksudnya yaitu "empat". Sebaliknya kalau seseorang mengucapkan kata "empat" dapat disimbolkan dengan " 4 ". Konsep adalah ide abstrak yang dapat digunakan untuk menggolongkan atau mengklasifikasikan sekumpulan objek tertentu merupakan contoh konsep atau bukan. Suatu konsep dalam lingkup matematika disebut konsep matematika. "Segitiga" adalah nama suatu konsep abstrak. Dengan konsep sekumpulan objek dapat digolongkan sebagai contoh atau bukan contoh. Konsep berhubungan erat dengan definisi. Definisi adalah ungkapan yang membatasi suatu konsep. Dengan adanya definisi ini orang dapat membuat ilustrasi, gambar, atau lambang dari konsep yang didefinisikan. Sehingga menjadi semakinjelas apa yang dimaksud dengan konsep tertentu. Operasi dalam matematika adalah prosedur-prosedur dan merupakan suatu proses untuk mencari hasil tertentu. Jika konsepnya himpunan maka operasi yang mungkin adalah gabungan, irisan, selisih atau komplemen. Selain dalam himpunan, dalam matematika dikenal operasi penjumlahan, selisih, perkalian, dan pembagian. Prinsip adalah hubungan antara berbagai objek dasar dalam matematika yang komplek daan terdiri atas beberapa fakta. Prinsip yang bernilai benar adalah prinsip yang memuat dua konsep atau lebih dan menyatakan hubungan antara konsep-konsep tersebut. Misal hasil kali dua bilangan $\mathrm{p}$ dan $\mathrm{q}$ sama dengan nol jika dan hanya jika $\mathrm{p}=0$ atau $\mathrm{q}=0$.

Objek tidak langsung matematika berkaitan dengan kemampuan berpikir logis, memecahkan masalah, berpikir analitis, sikap positip terhadap matematika, ketelitian, ketekunan, kedisiplinan dan hal lain yang secara implisit akan diperoleh jika seseorang mempelajari matematika. Berdasarkan pendapat Gagne di atas, dapat disimpulkan bahwa salah satu objek yang dipelajari dalam matematika adalah konsep. Pengenalan konsep dalam matematika dapat dilakukan melalui pembelajaran. Djamarah (2008) menyatakan seseorang yang telah memiliki konsep mampu melakukan 
abstraksi sehingga dapat menterjemahkan dan menghadirkan kesadaran dan membentuk representasi mental. Selama memahami konsep, seseorang memerlukan kemampuan dan strategi atau cara tertentu. Duffin \& Simpson (2000) menyatakan kemampuan yang dimiliki seseorang selama memahami konsep diharapkan dapat mengungkapkan kembali apa yang telah dikomunikasikan dengan sumber belajar, dan pada akhirnya ketika konsep telah dikuasai dapat dijawab masalah-masalah yang diberikan.

Polya (1988) menyebut empat langkah dalam menyelesaikan masalah yaitu memahami masalah, merencanakan tindakan, melaksanakan rencana, dan melihat kembali tindakan yang telah dilakukan. Langkah yang dikemukakan Polya dalam menyelesaikan masalah merupakan aktivitasyangdapatdiamatiselamapembelajaran dan merupakan indikator dalam menentukan ketuntasan hasil belajar. Ketuntasan hasil belajar menurut taksonomi Bloom dibedakan dalam ranah kognitif, afektif, dan psikomotorik. Khusus dalam ranah kognitif, Anderson \& Krathwohl (2001) mengembangkannya dalam dimensi proses kognisi dan dimensi pengetahuan. Proses kognisi meliputi mengingat, memahami, aplikasi, analisis, evaluasi, dan mencipta, Sedangkan pengetahuan terbagi ke dalam pengetahuan faktual, konseptual, prosedural, dan metakognisi.

Metakognisi terdiri dari kata meta dan kognisi. Meta dalam bahasa Yunani berarti setelah, sesudah, atau dibelakang. Kognisi merupakan proses memperoleh pengetahuan. (Zahmeister \& Neyberg. 1982). Selama prosesnya, metakognisi dapat dikaitkan dengan kegiatan pemecahan masalah, pengetahuan, proses kognisi dan strategi yang digunakan selama pembelajaran berlangsung. Istilah metakognisi mula-mula digunakan oleh Flavell pada tahun 1976. Menurut Flavell metakognisi terdiri dari pengetahuan, pengalaman dan regulasi yang befungsisebagaiunsurpentingdanberkontribusi terhadap suksesnya pemecahan masalah. Fakta yang ditemukan beberapa mahasiswa selama memecahkan masalah seseorang sering mengalami kegagalan. Kegagalan disebabkan oleh kurangnya pemahaman seseorang dalam aspek-aspek metakognisi terutama yang berkaitan dengan langkah-langkah yang harus ditempuh seseorang ketika memecahkan masalah. (Schoenfeld, 1992; Goos, 1995;). Seiring dengan semakin berkembangnya penelitian terutama yang berkaitan dengan proses metakognisi, ditemukan bahwa metakognisi dapat membantu proses berpikir seseorang lebih efektif dan terbuka (Clarke, 2004). Sementara Schoenfeld (1992) menganggap bahwa kesulitan dalam pemecahan masalah sangat terkait dengan ketidakmampuan siswa untuk memantau dan aktif mengatur proses kognisi pada dirinya sendiri.

Beberapa penelitian yang berhubungan dengan metakognisi dan pemecahan masalah telah banyak dilakukan, antara lain Desoete (2001), Lioe (2003), Wilson \& Clarke (2004), Cromley (2005), Efklides (2006), Lesh (2007), Panauorra (2009), Kuzle (2011), Molenar (2011), Karan \& Irizary (2011), Magiera \& Zawojewski (2011), In'am (2012), Praba (2013), Zarimah \& Tajudin (2013). Penelitian-penelitian tersebut secara umum membahas terjadinya proses metakognisi pada subjek penelitian namun belum mengungkap secara khusus karakteristik proses metakognisi mahasiswa dalam menyelesaikan masalah. Berkaitan dengan hal dimaksud, peneliti melakukan penelitian yang bertujuan untuk menganalisisdanmendeskripsikankarakateristik proses metakognisi mahasiswa matematika dalam menyelesaikan masalah kalkulus. Karakteristik proses metakognisi mahasiswa yang dideskripsikan berdasarkan terjadinya proses awareness, evaluation, dan regulation yang merupakan komponen metakognisi.

Friedrichs \& Hoyt (1976) menyebut metakognisi dengan istilah metamemory, sementara Veenman (2012) menggambarkan metakognisi sebagai dua bagian pokok yaitu pengetahuan metakognisi dan regulasi atau pemantauan metakognisi. Pengetahuan metakognisi merupakan penawaran dengan interaksi antara pengetahuan dan kemampuan seseorang untuk melakukan tugas-tugas, sifat tugas, dan strategi yang dapat digunakan untuk memenyelesaikan tugas. Regulasi atau pemantauan metakognisi meliputi kegiatan yang berkaitan dengan perencanaan, monitoring, evaluasi seseorang, dan proses kognisi dalam rangka mengatur proses yang terjadi. Metakognisi sebagai suatu proses memiliki empat aspek penting. Menurut Baker \& Brown (1984) aspek penting metakognisi adalah pengaturan diri, perencanaan, evaluasi, dan monitoring. Wellman (1985) menyatakan bahwa metakognisi sebagai suatu bentuk kognisi atau proses berpikir dua tingkat lebih 
yang melibatkan pengendalian terhadap aktivitas kognisi. Karena itu, metakognisi dapat dikatakan sebagai berpikir seseorang tentang berpikir pada dirinya sendiri atau pengetahuan seseorang tentang kognisi yang dimiliki.

Selain memiliki empat aspek, metakognisi menurut Schoenfeld (1992) sebagai proses berpikir seseorang tentang apa yang telah dipikirkannya dan merupakan interaksi antara tiga aspek penting yaitu: pengetahuan tentang proses berpikir, pengontrolan atau pengaturan diri, intuisi. Interaksi ini sangat penting karena pengetahuan tentang proses kognisi dapat membantu dan mengatur halhal di sekitar kita dan menyeleksi strategi-strategi untuk meningkatkan kemampuan kognisi kita selanjutnya. Proses metakognisi menurut Schoenfeld mencakup kemampuan untuk bertanya dan menjawab pertanyaan tentang suatu hal, topik dan masalah subjek, lamanya waktu yang digunakan siswa untuk mempelajari topik tertentu, strategi, metode dan taktik yang digunakan, tingkatan yang sedang dipelajari siswa, kesalahan yang dilakukan siswa, dan melakukan revisi suatu rencana yang akan dilakukan.

Livingstone (1997) mendefinisikan metakognisi sebagai thinking about thinking atau berpikir tentang berpikir. Dengan kata lain metakognisi adalah kemampuan berpikir seseorang tentang apa yang dipikirkannya, sehingga objek metakognisi adalah proses berpikir yang terjadi pada diri sendiri. Biryukov (2003) mengemukakan bahwa metakognisi merupakan dugaan pemikiran seseorang tentang apa yang telah dipikirkan sebelumnya dan meliputi pengetahuan, keterampilan dan pengalaman. Pengetahuan berupa kesadaran tentang apa yang diketahui, keterampilan berbentuk kesadaran tentangsesuatuyang dilakukan, dan pengalaman merupakan kesadaran tentang kemampuan kognisi yang dimiliki.

Davidson \& Sternberg (1998), menyatakan bahwa metakognisi berfungsi sangat penting dan berkontribusi terhadap kesuksesan pemecahan masalah yang memungkinkan individu untuk mengidentifikasi dan bekerja secara strategis. Matlin (1998) menyatakan bahwa metakognisi adalah pengetahuan yang berkaitan dengan kesadaran dan proses kognitif. Wellman (1985) menyatakan bahwa metakognisi sebagai suatu bentuk kognisi, atau proses berpikir dua tingkat atau lebih yang melibatkan pengendalian terhadap aktivitas kognisi. Karena itu, metakognisi dapat dikatakan sebagai berpikir seseorang tentang berpikirnya sendiri atau kognisi seseorang tentang kognisinya sendiri.

Tan (2003) menyatakan bahwa metakognisi adalah perhatian (thoughtfulness) yang mengacu pada berpikir tentang pemikiran sendiri, memeriksa sendiri dan mengolah informasi dan bagaimana memproses informasi secara efektif. Lioe (2003) menyatakan bahwa metakognisi merupakan kesadaran seseorang tentang proses kognisi dan kemandirian untuk mencapai tujuan tertentu. Metakognisi muncul dalam pemecahan masalah yang komponennya berupa sikap, keterampilan, konsep, proses, dan metakognisi.

Peirce (2003) mendefinisikan metakognisi secara umum dan secara khusus. Secara umum metakognisi adalah berpikir tentang berpikir. Sedangkan secara khusus, Peirce mengutip definisi metakognisi yang dibuat oleh Taylor, yang menyatakaan bahwa metakognisi merupakan apresiasi terhadap apa yang sudah diketahui yang berhubungan dengan kemampuan untuk membuat kesimpulan yang benar tentang bagaimana menerapkan pengetahuan strategis seseorang terhadap situasi tertentu, dan untuk melakukannya secara efisien dan andal. Taccasu (2008) mendiskripsikan metakognisi sebagai bagian dari perencanaan, monitoring dan evaluasi proses pembelajaran, berpikir tentang apa yang kita tahu atau tidak tahu dan mengatur bagaimana belajar yang melibatkan kedua kesadaran dan kontrol sadar belajar seseorang sehingga belajar akan efektif. Mokos \& Kafoussi (2013) menyatakan, metakognisi adalah kemampuan seseorang untuk memantau dan mengontrol dirinya sendiri terhadap sesuatu yang diketahuinya. Selama pembelajaran matematika merupakan hal yang penting tetang adanya suatu penelitian proses metakognisi siswa selama beraktivitas menyelesaikan masalah yang lebih difokuskan pada ranah pemecahan masalah yang berkaitan dengan matematika.

Berdasarkan beberapa definisi yang telah dikemukan di atas dapat diidentifikasi pokokpokok pengertian tentang metakognisi yaitu (1) metakognisi merupakan kemampuan jiwa yang termasuk dalam kelompok kognisi, (2) metakognisi merupakan kemampuan untuk menyadari, mengetahui, proses kognisi yang terjadi pada diri sendiri, metakognisi merupakan kemampuan untuk mengarahkan proses kognisi yang terjadi pada diri sendiri. (3) 
metakognisi merupakan kemampuan belajar bagaimana mestinya belajar dilakukan yang meliputi proses perencanaan, pemantauan, dan evaluasi, metakognisi merupakan aktivitas berpikir tingkat tinggi karena aktivitasnya mampu mengontrol proses berpikir yang sedang berlangsung pada diri sendiri, dan (5) metakognisi berkaitan dengan proses berpikir siswa tentang berpikirnya agar menemukan strategi yang tepat dalam memecahkan masalah (6) keterampilan metakognisi sangat penting dalam memecahkan masalah matematika, sehingga keterampilan tersebut perlu ditingkatkan.Untukmeningkatkanketerampilan metakognisi diperlukan adanya kesadaran yang harus dimiliki siswa pada setiap langkah berpikirnya. Kesadaran siswa dalam berpikir ketika menyelesaikan suatu masalah.

Magiera \& Zawojewski (2011) menemukan bahwa aktivitas metakognisi terjadi selama pemberian tugas di kelas. Metakognisi yang terjadi pada siswa memiliki tiga komponen yaitu awareness, evaluation, dan regulation. Selama proses metakognisi terjadi, dapat dilihat aktivitas yang muncul dalam setiap komponen metakognisi yang disebut sebagai tipe-tipe aktivitas metakognisi. Tipe-tipe aktivitas metakognisi awareness meliputi apa yang diketahui oleh siswa, apa yang dibutuhkan siswa untuk menyelesaikan masalah, apa yang harus dilakukan siswa, dimana siswa dalam proses menyelesaikan masalah. Tipe-tipe aktivitas evaluation meliputi penilaian hasil, penilaian masalah kesulitan siswa, penilaian kemajuan, kemampuan atau pemahaman. Tipe-tipe aktivitas regulation meliputi strategi dalam perencanaan, memilih startegi dalam pemecahan masalah, perumusan tujuan.

Awareness menurut Wilson \& Clarke (2002, 2004) berkaitan dengan kesadaran seseorang dalam proses pembelajaran atau dalam proses memecahkan masalah, isi pengetahuan khusus yang dimiliki, dan pengetahuan seseorang tentang pembelajaran atau strategi dalam memecahkan masalah. Hal ini juga mencakup pengetahuan seseorang tentang apa yang perlu dilakukan, apa yang telah dilakukan, dan apa yang dapat dilakukan dalam konteks pembelajaran tertentu atau situasi memecahkan masalah.Evaluation mengacu pada penilaianyang dibuat oleh seseorang tentang proses berpikir, kemampuan dan keterbatasan seperti bekerja di dalam situasi tertentu atau sebagai kelengkapan dirinya sendiri. Misalnya, orang dapat membuat penilaian mengenai efektivitas pemikiran yang dilakukan atau strategi yang dipilih. Regulation dalam metakognisi terjadi ketika seseorang memanfaatkan keterampilan metakognisinya untuk mengarahkan pengetahuan dan pemikirannya dan mengacu pada pengetahuan individu yang berupa strategi, termasuk bagaimana dan mengapa menggunakan strategi tertentu, serta menggunakan keterampilan seperti perencanaan, koreksi diri, menetapkan tujuan untuk mengoptimalkan penggunaan sumber daya kognitif mereka sendiri.

Komponen metakognisi yang dikemukakan oleh Wilson \& Clarke $(2002,2004)$ dan Magiera \& Zawojeski (2011) memiliki indikator-indikator sebagai variabel dan ukuran. Namun demikian bagaimana proses terjadinya perubahan antar komponen metakognisi belum dianalisis lebih mendalam. Sriraman (2003) telah melakukan pertimbangan terhadap siswa mengenai hubungan antara pengetahuan mereka dan apa yang dibutuhkan pada situasi masalah yang diberikan, demikian pula Stillman \& Galbraith (1998). Evaluation telah didiskripsikan dan diteliti mengenai refleksi eksplisit siswa selama proses pemecahan masalah, peranan evaluasi dalam menentukan strategi pemecahan masalah. Pengambilan keputusan dalm evaluasi sistimatik, rencana alternatif, dan strategi dalam menyelesaikan masalah (Lester, 1980; Lester, Garofalo \& Kroll, 1989). Regulation telah dijelaskan dalam bentuk fleksibilitas siswa dalam memilih sebuah rencana solusi, memilih strategi, dan implementasi rencana yang telah dikembangkan oleh Lester (1989) dan Zan (2000).

\section{METODE}

Penelitian yang dilakukan merupakan penelitian deskriptif kualitatif dengan subjek penelitian 23 mahasiswa jurusan matematika yang telah menempuh mata kuliah Kalkulus Diferensial. Subjek penelitian terdiri dari 6 mahasiswa berkemampuan tinggi, 9 mahasiswa berkemampuan sedang dan 8 mahasiswa berkemampuan rendah. Metode penelitian disusun berdasarkan tahapan-tahapan (1) peneliti memberikan masalah kalkulus kepada mahasiswa berupa soal tentang aplikasi turunan fungsi untuk menentukan nilai maksimum dan minimum. Soal telah divalidasi oleh 2 orang 
ahli dalam bidang matematika dan pendidikan matematika. Selama menyelesaikan masalah kalkulus, subjek melakukan think-alouds dan direkam. Masalah yang diberikan kepada subjek penelitian terlampir dalam artikel. (2) peneliti melakukuan pengamatan kepada siswa selama proses think-aloud dengan menggunakan lembar pengamatan yang bertujuan untuk mengetahui munculnya indikator dan deskriptor awarenes, evaluation, dan regulasi. (3) Peneliti mengkoreksi hasil kerja mahasiswa yang berpandu pada kisikisi jawaban masalah kalkulus yang telah dibuat sebelumnya.

Berdasarkan koreksi yang dilakukan, hasil kerja subjek penelitian dikelompokkan dalam mahasiswa berkemampuan tinggi, sedang, dan rendah. (4) Memberikan angket. Angket diberikan setelah mahasiswa menyelesaikan masalah kalkulus. Pertanyaan angket sebanyak 14 item dan bertujuan untuk mengukur proses metakognisi yang terjadi pada mahasiswa. Angket yang dibuat merupakan hasil pengembangan penelitian yang dilakukan oleh Biryukov (2001), Azsoy \& Ataman (2009), Meriam \& Idrus (2010), Panaoura (2010), Sengul \& Katransi (2013). (5) melakukan wawancara. Wawancara didasarkan pada hasil kerja mahasiswa, rekaman think-aloud, jawaban angket. Wawancara yang dilakukan bertujuan untuk mengetahui secara lebih mendalam karakteristik proses awareness, evaluation, dan regulation. Wawancara dilakukan setelah mahasiswa melakukan think-alouds. Protokol wawancara disusun dengan mengembangkan indikator-indikator awareness, evaluation, dan regulation. (6) melakukan transkripsi rekaman think-alouds dan wawancara. Transkripsi yang dilakukan bertujuan untuk mendapatkan data masingmasing subjek penelitian tentang karakteristik proses metekognisi selama menyelesaikan masalah kalkulus dalam hubungannya dengan kemampuan mahasiswa. (7) mereduksi data. Reduksi data dilakukan dengan membuat abstraksi berupa rangkuman inti data, proses dan pernyataan-pernyataan yang dilakukan oleh subjek penelitian dalam menyelesaikan masalah kalkulus serta menyusun data dalam satuansatuan yang selanjutnya dikategorisasikan dengan cara cooding. (8) analisis data, menganalisis proses metakognisi setiap subjek penelitian melalui masing-masing indikator awareness, evaluation, dan regulation. 9) Validasi data, validasi data dilakukan dengan teknik triangulasi dan pemeriksaan teman sejawat melalui diskusi. Triangulasi yang digunakan adalah triangulasi sumber yaitu membandingkan hasil pengamatan selama subjek menyelesaikan masalah kalkulus, lembar pengamatan, hasil kerja mahasiswa, thinkalouds, jawaban angket dan hasil wawancara.

\section{HASIL DAN PEMBAHASAN}

Data penelitian berupa hasil kerja. rekaman think-aloud, lembar pengamatan, jawaban angket metakognisi dan transkrip wawancara subjek penelitian dikaji dan dianalisis secara kualitatif. Kerangka teori yang dibangun oleh peneliti adalah menganalisis karakteristik proses metakognisi mahasiswa dalam menyelesaikan masalah kalkulus melalui indikator awareness, evaluation, dan regulation. Berdasarkan kerangka teori yang dibangun tersebut, hasil analisis penelitian dikelompokan dalam kategori karakteristik proses metakognisi mahasiswa berkemampuan tinggi, sedang dan rendah.

Hasil penelitian yang bersumber dari 23 mahasiswa Jurusan Pendidikan Matematika yang telah menempuh mata kuliah Kalkulus Diferensial yang diberi masalah kalkulus dan selama menyelesaikan masalah muncul komponen awareness, evaluation, dan regulation. Selain munculnya komponen metakognisi secara lengkap, subjek penelitian dalam menyelesaikan masalah yang diberikan mempunyai pola yang relatif sama sehingga analisis selanjutnya adalah mengelompkkan subjek dalam subjek berkemampuan tinggi, sedang, dan rendah. Berdasarkan hal tersebut 23 subjek penelitian terdiri dari 6 subjek penelitian berkemampuan tinggi, 9 berkemampuan sedang dan 8 berkemampuan rendah.

Berdasarkan hasilanalisis data denganmenggunakan metode perbandingan tetap dari Glaser dan Strauss dan validasi data dengan traingulasi dengan masing-masing subjek penelitian dalam setiap kelompok memiliki karakteristik yang relatif sama sehingga pemaparan data hanya dilakukan sebanyak 6 subjek penilitian. Subjek penelitian tersebut adalah S-1 dan S-2 dari kelompok berkemampuan tinggi, S-3 dan S-4 dari kelompok berkemampuan sedang, dan S-5 dan S-6 dari kelompok berkemampuan rendah. Ketiga kelompok subjek penelitian selanjutnya dikaji karakteristik proses metakognisi melalui indikatornya komponen awareness, evaluation, dan regulation. 
86 | Dwi Purnomo, Karakteristik Proses Metakognisi Mahasiswa ...

Komponen awareness memiliki 5 indikator yaitu subjek penelitian memikirkan kembali tentang apa yang diketahui dari masalah kalkulus yang diberikan (A1), memikirkan kembali pertanyaan dalam masalah kalkulus dan mengkaitkannya dengan masalah sejenis yang telah diperoleh dan diselesaikan sebelumnya (A2), memikirkan kembali tentang sesuatu yang belumdapatdiselesaikanpadawaktusebelumnya ketika menyelesaikan masalah kalkulus yang diberikan (A3), memikirkan kembali langkah selanjutnya yang harus dilakukan untuk menyelesaikan masalah kalkulus yang diberikan (A4), dan memikirkan kembali langkah-langkah yang telah dilakukan ketika menjawab masalah kalkulus yang diberikan (A5).

Komponenevaluation mempunyai5indikator yaitu subjek penelitian memikirkan kembali cara yang digunakan dalam menyelesaikan masalah kalkulus yang diberikan (E1), Memikirkan kembali urutan dan langkah-langkah yang harus dilakukan pada saat menyelesaikan masalah kalkulus yang diberikan (E2), memeriksa kembali hasil jawaban masalah kalkulus yang telah diselesaikan (E3), memikirkan kembali benar tidaknya jawaban masalah kalkulus yang telah diselesaikan (E4), dan memikirkan kembali kegagalan yang dilakukan dalam menjawab masalah kalkulus yang diberikan dengan cara sebelumnya (E5).

Komponen regulation memiliki 4 indikator yaitu subjek penelitian Memikirkan kembali dan membuat rencana untuk segera menyelesaikan masalah kalkulus yang diberikan (R1), memikirkan kembali perbedaan cara yang digunakan dalam menjawab masalah kalkulus yang diberikan (R2), memikirkan kembali tentang apa yang dilakukan selanjutnya setelah selesai menjawab masalah kalkulus (R3), dan memikirkan kembali bagimana mengubah cara dalam menyelesaikan masalah kalkulus yang diberikan (R4). Proses terjadinya metakognisi subjek penelitian dan karakteristiknya dapat dijelaskan sebagai berikut.

\section{Proses Metakognisi Mahasiswa dengan Ke- mampuan Tinggi}

Subjek penelitian S-1, dan S-2 memiliki karakteristik proses metakognisi yang relatif sama. Selama proses metakognisi S-1, dan S-2 menunjukkan aktivitas yang mengambarkan karakteristik dari indikator komponen awareness, evaluation, dan regulation. Ketika menyelesaikan masalah kalkulus indikator-indikator tersebut muncul dalam urutan A1, A2, A3, A4, A5, E1, E2, E3, E4, E5, R1, R2, R3, dan R4.

Uraian masing-masing diskripstor dan munculnya indikator pada S-1 dan S-2 dapat dilihat pada gambar 4.1

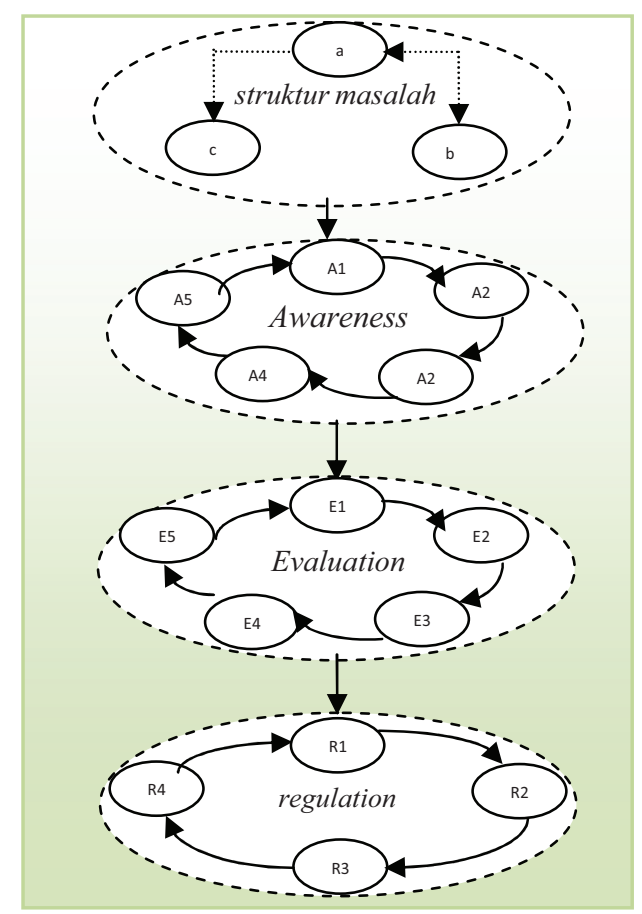

Gambar 4.1 Proses Metakognisi S-1 dan S-2

\section{Proses Metakognisi Mahasiswa dengan Ke- mampuan Sedang}

Subjek penelitian berkemampuan sedang yaitu S-3 dan S-4 melakukan proses metakognisi dengan indikator lengkap tetapi tidak berurut. Ketika menyelesaikan masalah kalkulus indikator pada S-3 muncul dengan urutan A1, A2, A3, A5, A4, E1, E2, E3, E4, E5, R1, R3, R2, dan R4. Indikator pada S-4 muncul dengan urutan A1, A2, A3, A4, A5, E1, E2, E3, E4, E5, R1, $\mathrm{R} 2, \mathrm{R} 4, \mathrm{R} 3$.

Urutan munculnya indikator pada S-3 dapat dilihat pada gambar 4.2 dan urutan munculnya indikator pada S-4 dapat dilihat pada gambar 4.3 


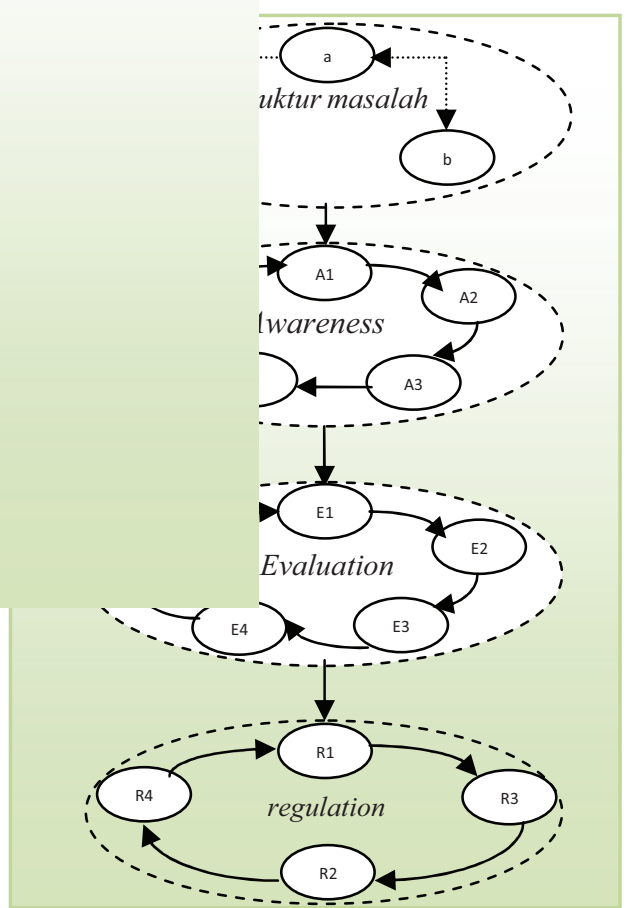

Gambar 4.2 Proses Metakognisi S-3

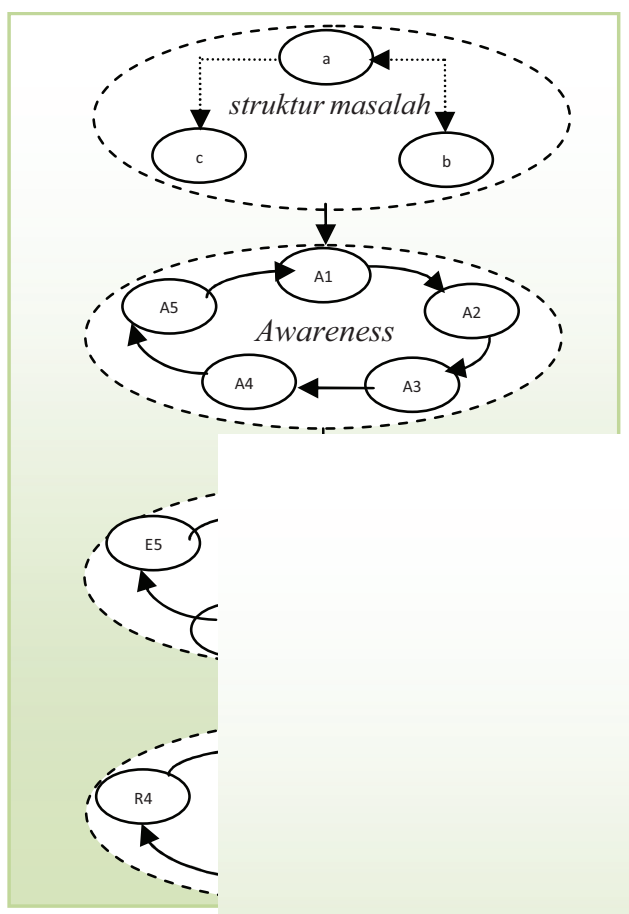

Gambar 4.3 Proses Metakognisi S-4

\section{Proses Metakognisi Mahasiswa dengan Ke- mampuan Rendah}

Subjek penelitian berkemampuan rendah adalah S-5, dan S-6. Perubahan proses metakognisi S-5, dan S-6 menunjukkan aktivitas yang mengambarkan karakteristik dari indikator awareness, evaluation, dan regulation. Ketika menyelesaikan masalah kalkulus indikator pada S-5 muncul dengan urutan A1, A3, A2, A4, A5, E1, E2, E3, E4, R1, R3, R2, R4. Indikator pada S-6 muncul dengan urutan A1, A2, A3, A4, E1, E2, E3, E4, E5, R1, R2, R4, R3.

Urutan munculnya indikator pada S-5 dapat dilihat pada gambar 4.4 dan urutan munculnya indikator pada S-6 dapat dilihat pada gambar 4.5

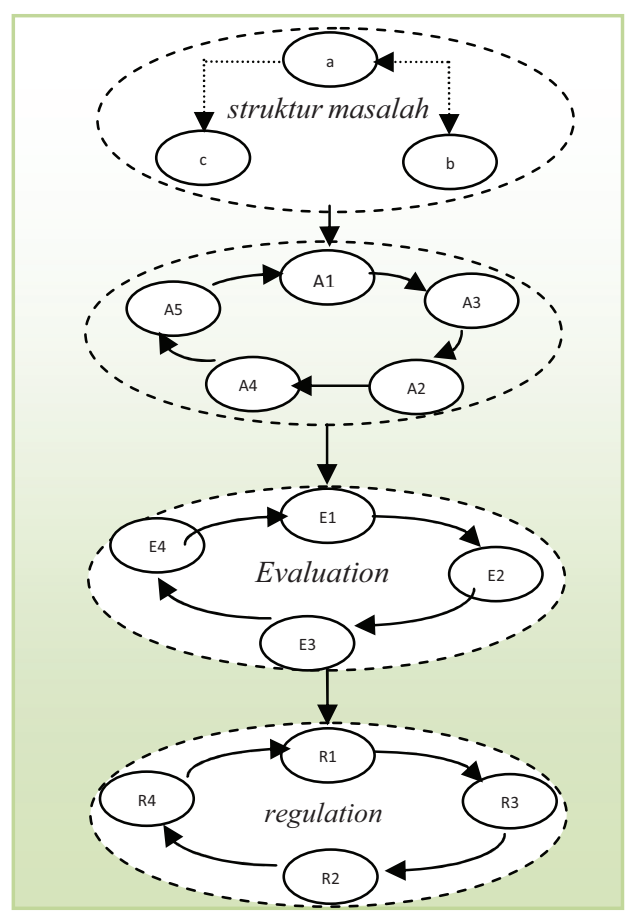

Gambar 4.4 Proses Metakognisi S-5

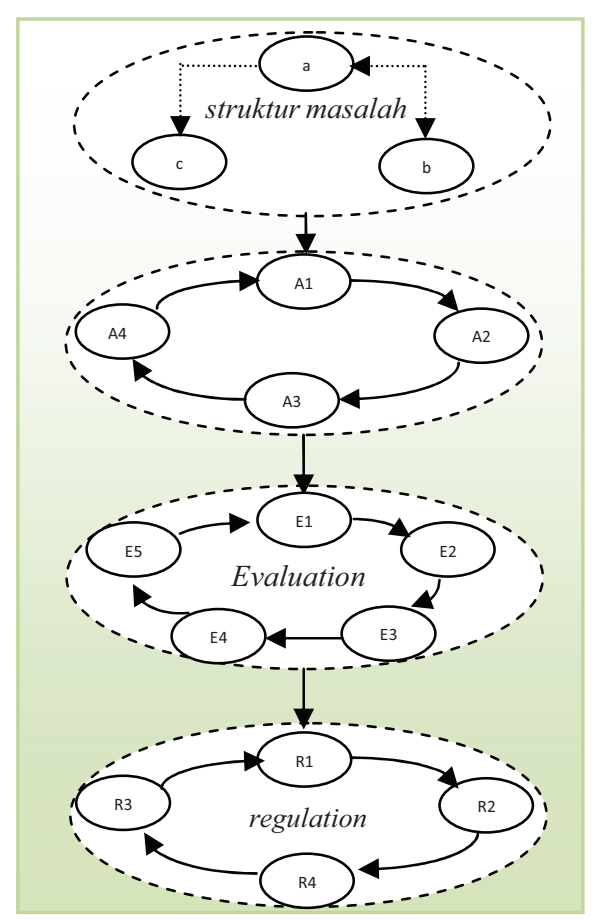

Gambar 4.5 Proses Metakognisi S-6 
88 | Dwi Purnomo, Karakteristik Proses Metakognisi Mahasiswa ...

Temuan hasil penelitian di atas dapat dihubungan dengan teori sebelumnya sebagai landasan dalam penelitian yang telah dilakukan. Jika dikaitkan dengan pendapat Wilson dan Clarke $(2002,2004)$ maka masing-masing karakteristik setiap komponen merupakan aktivitas yang berkaitann dengan kemampuan seseorang untuk dapat memikirkan apa yang telah dilakukannya ketika menyelesaikan masalah. Masalah dalam penelitian adalah bagaimana subjek penelitian dapat menemukan langkah yang diyakininya sebagai jawaban masalah kalkulus yang diberikan. Keyakinan subjek penelitiam didasari oleh proses evaluasi dan regulasi yang telah dilakukan dan merupakan bagian dari kemampuannya untuk memantau dan mengontrol dirinya sendiri terhadap sesuatu yang diketahuinya. kontrol diri dapat dilakukan ketika menyelesaikan masalah (Mokos \& Kafoussi, 2013). Berkaitan dengan indikator selama proses metakognisi terjadi, dapat dilihat bahwa aktivitas sebagai tipe-tipe aktivitas metakognisi. Tipe aktivitas kesadaran meliputi apa yang diketahui oleh siswa, apa yang dibutuhkan siswa untuk menyelesaikan masalah, apa yang harus dilakukan siswa, dimana siswa dalam proses menyelesaikan masalah. Tipe aktivitas evaluasi meliputi penilaian hasil, penilaian masalah kesulitan siswa, penilaian kemajuan, kemampuan atau pemahaman. Tipe aktivitas regulasi meliputi strategi dalam perencanaan, memilih startegi dalam pemecahan masalah, perumusan tujuan. Magiera \& Zawojewski (2011)

\section{KESIMPULAN DAN SARAN}

Berdasarkan analisis data dapat disimpulkan bahwa mahasiswa berkemampuan tinggi karakteristik proses metakognisi dalam menyelesaikan masalah kalkulus lengkap dan terurut, mahasiswa berkemampuan sedang karakteristik proses metakognisinya lengkap tetapi tidak terurut sedangkan mahasiswa berkemampuan rendah karakteristik proses metakognisinya tidak lengkap.

Karakteristik proses metakognisi lengkap dan terurut pada S-1 dan S-2, karakteristik proses metakognisi lengkap tidak terurut pada S-3 dan S-4, dan karakteritik proses metakognisi tidak lengkap pada S-5 dan S-6 dapat dirinci sebagai berikut: Komponen awareness dengan A1 memunculkan 6 karakteristik, A2 memunculkan 7 karakteristik, A3 memunculkan 5 karakteristik, A4 memunculkan 8 karakteristik, dan A5 memunculkan 4 karakteristik. Komponen evaluation dengan indikator E1 memunculkan 4 karakteristik,E2 memunculkan5karakteristik,E3 memunculkan 6 karakteristik, E4 memunculkan 4 karakteristik, dan E5 memunculkan 4 karakteristik. Komponen regulation dengan indikator R1 memunculkan 5 karakteristik, R2 memunculkan 4 karakteristik, R3 memunculkan 4 karakteristik, dan R4 memunculkan 6 karakteristik.

Secara keseluruhan semua karakteristik yang muncul pada setiap subjek penelitian dapat dijelaskan pada tabel di bawah ini.

Tabel 1.Temuan Indikator dan Karakteristik Proses Metakognisi

\begin{tabular}{|c|c|c|}
\hline \multicolumn{3}{|r|}{ Komponen Awareness } \\
\hline Title & Indikator & Karakteristik \\
\hline A1 & $\begin{array}{l}\text { Memikirkan kem- } \\
\text { bali tentang apa } \\
\text { yang diketahui dari } \\
\text { masalah kalkulus } \\
\text { yang diberikan. }\end{array}$ & $\begin{array}{l}\text { Subjek penelitian: } \\
\text { 1. Membaca masalah yang diberikan berulang-ulang dan memberi tanda } \\
\text { pada kata-kata yang dianggap sebagai kata kunci. } \\
\text { 2. Mencatat hal-hal penting pada masalah dengan memberi garis bawah } \\
\text { pada kata-kata yang dianggap sebagai kata kunci. } \\
\text { 3. Memeriksa gambar pada masalah dan memisalkan panjang dan lebar } \\
\text { gambar sebagai variabel } x \text { dan } y \text {. } \\
\text { 4. Membaca tabel pada masalah dan mencatatnya sebagai hal yang dike- } \\
\text { tahui dan membandingkan isi masing-masing kandang sebagai bagian } \\
\text { dari yang diketahui pada masalah. } \\
\text { 5. Membuat catatan penting dan menyimpulkan hal-hal yang diketahui } \\
\text { sebagai syarat untuk menentukan cara menyelesaikan masalah yang } \\
\text { diberikan. } \\
\text { 6. Membuat hubungan antara hal-hal yang diketahui dalam masalah } \\
\text { dengan masing-masing pertanyaan yang akan dijawab pada masalah } \\
\text { yang diberikan. }\end{array}$ \\
\hline
\end{tabular}




\begin{tabular}{|c|c|}
\hline Title & Indikator \\
\hline A2 & $\begin{array}{l}\text { Memikirkan kem- } \\
\text { bali pertanyaan dalam } \\
\text { masalah kalkulus dan } \\
\text { mengkaitkannya den- } \\
\text { gan masalah sejenis } \\
\text { yang telah diselesai- } \\
\text { kan sebelumnya. }\end{array}$ \\
\hline
\end{tabular}

\section{Komponen Awareness}

Subjek penelitian:

1. Membaca masing-masing pertanyaan pada masalah secara berulang dan menghubungkannya dengan pernyataan sebelumnya pada masalah sebagai hal yang diketahui.

2. Memberi tanda pada kata-kata yang dianggap sebagai kata kunci dan inti masing-masing pertanyaan pada masalah serta menyimpulkan halhal yang ditanyakan dalam masalah.

3. Membuat hubungan pertanyaan (a) dalam masalah yang berkaitan dengan luas persegi panjang. Hubungan yang dibuat antara luas (L) dengan panjang dan lebar adalah $L=x y$ atau $L=5 x y$ tergantung dari pemisalan yang dilakukan untuk panjang dan lebar yang telah dimisalkan sebelumnya.

4. Membuat hubungan antara panjang kawat berduri yang disediakan (s) pada masalah dengan bagian kandang yang dipagari dalam bentuk persamaan $s=x+6 y$ atau $s=5 x+6 y$. Karena diketahui panjang kawat berduri 240 meter, sehingga terdapat dua persamaan yang dapat ditulis yaitu $240=x+6 y$ atau $240=5 x+6 y$.

5. Menyatakan luas persegi panjang pada masalah yang diketahui sebagai suatu fungsi yang memuat variabel yang telah ditetapkan sebelumnya, yaitu panjang dan lebar sebagai variabelnya.

6. Mengubah fungsi luas persegi panjang pada masalah sebagai fungsi satu variabel dengan menentukan syarat maksimum luas suatu bidang.

7. Membuat simpulan tentang hal-hal yang ditanyakan dalam masalah yang ditanyakan berdasarkan catatan yang telah dibuatnya.

A3 Memikirkan kembali tentang sesuatu yang belum dapat diselesaikan pada waktu sebelumnya ketika menyelesaikan masalah kalkulus yang diberikan.
Subjek penelitian:

1. Membuat hubungan antara panjang kawat berduri dengan bagian kandang yang diberi pagar sebagai persamaan $240=x+6 y$ atau $240=4 x+6 y$.

2. Menyatakan luas kandang dalam bentuk fungsi satu peubah sebagai $L=x$ menjadi bentuk $L=x(240-6 x)$

3. Menyatakan luas kandang dalam bentuk fungsi satu peubah sebagai $L=5 x y$ menjadi $L=5\left(\frac{240-6 y}{5}\right) y$.

4. Menuliskan turunan fungsi satu peubah dan menentukan syarat nilai maksimum dan minimum suatu fungsi sebagai $\frac{d L}{d x}=0$ atau $\frac{d L}{d y}=0$

5. Melakukan substitusi fungsi luas dalam satu peubah dan menurunkannya (derevative)

A4 Memikirkan kembali Subjek penelitian : langkah selanjutnya yang harus dilakukan untuk menyelesaikan masalah kalkulus yang diberikan.

2. Memilih cara yang digunakan untuk menyelesaikan masalah yang
1. Melihat kembali hal-hal yang diketahui pada masalah yang diberikan. diberikan berdasarkan pengetahuan yang diperoleh sebelumnya.

3. Menemukan nilai variabel yang telah ditetapkan setelah menurunkan fungsi luas yang dinyatakan dalam fungsi satu peubah.

4. Melakukan substiusi variabel yang telah diperoleh ke dalam fungsi sebelumnya yaitu $240=x+6 y$ atau $240=5 x+6 y$

5. Menemukan luas kandang keseluruhan dan masing-masing sebagai jawaban masalah yang diberikan.

6. Membaca ulang tabel pada masaah yang diberikan.

7. Menuliskan perbandingan luas masing-masing kandang dengan banyak kambing.

8. Menuliskan biaya bahan pembuatan kandang dan biaya operasinal selama satu minggu seperti yang tertera pada tabel pada masalah yang diberikan. 


\begin{tabular}{|c|c|c|}
\hline \multicolumn{3}{|r|}{ Komponen Awareness } \\
\hline Title & Indikator & Karakteristik \\
\hline A5 & $\begin{array}{l}\text { Memikirkan kem- } \\
\text { bali uraian jawaban } \\
\text { masalah kalkulus } \\
\text { yang diberikan. }\end{array}$ & $\begin{array}{l}\text { Subjek penelitian: } \\
\text { Membaca jawaban masalah berulang-ulang untuk mengetahui urutan dan } \\
\text { sistematika jawaban masalah sesuai dengan yang diminta dan disyaratkan } \\
\text { dalam pertanyaan (a), (b), dan (c). } \\
\text { Mencoba cara yang lain untuk menjawab masalah dan belum dilakukan } \\
\text { sebelumnya. } \\
\text { Mengulang-ulang cara baru dan melakukan pengecekan dengan hal-hal } \\
\text { yang diketahui dalam masalah. } \\
\text { Membandingkan uraian jawaban antara cara yang satu dengan cara yang } \\
\text { lain yang telah dikerjakan sebelumnya. }\end{array}$ \\
\hline E1 & $\begin{array}{l}\text { Memikirkan kembali } \\
\text { cara yang digunakan } \\
\text { dalam menyelesaikan } \\
\text { masalah kalkulus } \\
\text { yang diberikan. }\end{array}$ & $\begin{array}{l}\text { Subjek penelitian: } \\
\text { Membandingkan hasil masing-masing cara yang telah dilakukan dalam } \\
\text { menjawab pertanyaan pada masalah yang diberikan. } \\
\text { Menandai hal-hal penting pada cara-cara yang digunakan untuk menyele- } \\
\text { saikan masalah. } \\
\text { Mencatat hal penting perbedaan antara cara yang telah digunakan dalam } \\
\text { menyelesaikan masalah yang diberikan. } \\
\text { Membuat hubungan antara hal-hal yang telah diketahui dengan cara-cara } \\
\text { yang digunakan dalam menyelesaikan masalah yang diberikan. }\end{array}$ \\
\hline E2 & $\begin{array}{l}\text { Memikirkan kem- } \\
\text { bali tentang urutan } \\
\text { langkah-langkah yang } \\
\text { harus dilakukan pada } \\
\text { saat menyelesaikan } \\
\text { masalah kalkulus } \\
\text { yang diberikan. }\end{array}$ & $\begin{array}{l}\text { Subjek penelitian: } \\
\text { Mengecek ulang hubungan antara hal yang diketahui dengan hal yang } \\
\text { ditanyakan dalam masalah. } \\
\text { Memeriksa uraian jawaban yang telah dituliskan berdasarkan cara-cara } \\
\text { yang telah dilakukan. } \\
\text { Memeriksa kembali penulisan hubungan antara panjang kawat yang dise- } \\
\text { diakan pada masalah yang diberikan dengan bagian pagar yang dipagari. } \\
\text { Membaca tabel dan mengurutkannya antara banyaknya kambing setiap } \\
\text { kandang dengan luas masing-masing kandang. } \\
\text { Menandai hal-hal penting pada langkah jawaban masalah yang telah } \\
\text { dilakukan. }\end{array}$ \\
\hline E3 & $\begin{array}{l}\text { Memeriksa kembali } \\
\text { hasil jawaban masalah } \\
\text { kalkulus yang telah } \\
\text { diselesaikan. }\end{array}$ & $\begin{array}{l}\text { Subjek penelitian: } \\
\text { Mengecek syarat maksimun atau minimum fungsi satu peubah berdasar- } \\
\text { kan rumus luas yang telah dituliskan sebelumnya. } \\
\text { Melakukan perhitungan ulang panjang dan lebar kandang keseluruhan } \\
\text { dan masing-masing kandang berdasarkan tabel pada masalah yang diberi- } \\
\text { kan. } \\
\text { Menghitung ulang perbandingan antara luas kandang dengan banyaknya } \\
\text { kambing setiap kandang. } \\
\text { Menghitung ulang jumlah bahan pembuatan kandang. } \\
\text { Menghitung ulang biaya operasional seluruh kandang setiap minggu. } \\
\text { Menyimpulkan jawaban pertanyaan secara keseluruhan. }\end{array}$ \\
\hline E4 & $\begin{array}{l}\text { Memikirkan kembali } \\
\text { benar tidaknya jawa- } \\
\text { ban masalah kalkulus } \\
\text { yang telah diselesai- } \\
\text { kan. }\end{array}$ & $\begin{array}{l}\text { Subjek penelitian: } \\
\text { Membaca kembali jawaban pertanyaan }(\mathrm{a}),(\mathrm{b}) \text {, dan }(\mathrm{c}) \text { masalah berulang- } \\
\text { ulang untuk mengetahui benar tidaknya jawaban yang telah ditulis dalam } \\
\text { lembar jawab. } \\
\text { Membuat hubungan antara jawaban yang telah diperoleh dengan setiap } \\
\text { pertanyaan pada masalah yang diberikan. } \\
\text { Mencocokkan ukuran panjang dan lebar kandang yang telah diperoleh } \\
\text { dengan dengan panjang kawat berduri yang disediakan. } \\
\text { Melakukan perhitungan kembali soal (b) dan (c) dengan melihat kembali } \\
\text { tabel } 1 \text { pada masalah kalkulus. }\end{array}$ \\
\hline
\end{tabular}




\begin{tabular}{|c|c|}
\hline Title & Indikator \\
\hline E5. & $\begin{array}{l}\text { Memikirkan kem- } \\
\text { bali kegagalan yang } \\
\text { dilakukan dalam } \\
\text { menjawab masalah } \\
\text { kalkulus yang diberi- } \\
\text { kan dengan cara } \\
\text { sebelumnya. }\end{array}$ \\
\hline
\end{tabular}

R1 Memikirkan kembali membuat rencana untuk segera menyelesaikan masalah kalkulus yang diberikan

\section{Komponen Awareness}

Karakteristik

Subjek penelitian:

Membaca kembali jawaban setiap pertanyaan pada masalah yang diberikan untuk mengetahui nilai kebenaran.

Mengecek berulang-ulang jawaban tentang syarat dipenuhinya nilai maksimum atau minimum luas kandang seluruhnya pada pertanyaan (a). Mengecek berulang-ulang jawaban pertannyaan (b) tentang perbandingan banyaknya setiap kandang dengan luas masing-masing kandang sebagaimana syarat pada gambar (1) dan tabel (1) pada masalah kalkulus . Mengecek berulang-ulang jawaban (c) tentang biaya operasional total setiap minggu dan biaya pembuatan kandang sebagaimana yang disyarat pada tabel (1) pada masalah kalkulus .

\section{Subjek penelitian:}

Mengecek jawaban yang diberikan secara berulang-ulang sebelum menyimpulkannya.

Menetapkan cara yang paling tepat dan mudah untuk menjawab pertanyaan-pertannyaan masalah yang diberikan.

Mengurutkan jawaban dari masing-masing pertanyaan berdasarkan syarat yang telah diketahui sebelumnya.

Menandai kesalahan dalam menghitung pada jawaban masalah yang diberikan.

Membaca ulang tabel dan gambar pada masalah yang diberikan untuk menetapkan cara paling mudah dan tepat digunakan untuk menjawab masalah yang diberikan.

\section{R2 Memikirkan kembali Subjek penelitian:}

perbedaan cara yang digunakan dalam menjawab masalah kalkulus yang diberikan.

Melakukan pengecekan terhadap cara yang telah digunakan untuk menjawab pertanyaan dalam masalah yang diberikan.

Membandingkan cara yang telah digunakan untuk menyelesaikan masalah yang diberikan.

Mengurutkan jawaban pertanyaan pada masalah yang diberikan.

Menggunakan cara yang paling mudah dalam menjawab masalah untuk menjelaskan jawaban masing-masing soal dalam masalah.

R3 Memikirkan kembali Subjek penelitian:

tentang apa yang akan Membaca kembali hal-hal yang diketahui dalam masalah yang diberikan. dilakukan selanjutnya dalam memulai menjawab masalah kalkulus .

R4 Memikirkan kembali bagimana mengubah cara dalam menyelesaikan masalah kalkulus yang diberikan.
Memeriksa tabel dan gambar pada masalah.

Menetapkan cara yang digunakan untuk menjawab masalah yang diberikan.

Menetapkan jawaban pertannyaan masalah yang diberikan dengan membuat hubungan antara hal yang diketahui dengan yang ditanyakan.

\section{Subjek penelitian:}

Mengecek ulang jawaban pertanyaan masalah yang diberikan dan mencocokkan jawaban pada gambar persegi yang diketahui.

Menandai hal-hal penting pada jawaban yang telah diberikan.

Membuat kesimpulan pada jawaban dengan cara yang telah dilakukan.

Mengecek tingkat kesukaran jawaban yang telah dilakukan.

Memeriksa ulang jawaban yang telah ditulis.

Menyimpulkan masing-masing jawaban pertanyaan (a), (b), dan (c) pada masalah yang diberikan. 
92 | Dwi Purnomo, Karakteristik Proses Metakognisi Mahasiswa ...

\section{DAFTAR RUJUKAN}

Anderson, L.W. \& Krathwohl, D.R. 2001. A Taxonomy for Learning, Teaching, and Assessing (A Revision of Bloom's Taxonomy of Educational Objectives). New York: Addision Wesley Longman, Inc.

Baker, L. \& Brown, A. L. 1984. Metacognitive Skills and Rreading. In Douglas J. Hacker, John Dunlosky and Arthur C. Graesser (Eds.) Handbook of Metacognition in Education. (p. 7-25). New York: Routledge.

Biryukov, P. 2003. Metacognitive Aspects of Solving Combinatorics Problem Kaye College of Education. (Online), (www.cimt.plymouth.ac.uk), accesed 13 Februari 2014.

Charter, E. 2003. The Use of Think-aloud Methods in Qualitatif Research an Intruduction to Think-aloud Methodes. Brook Education. (Online), Volume 12 Number 3 2003. p. 68-82, (www. brock. scholarsportal), accesed 22 Agustus 2015.

Cromley, J.G. 2005. Metacognition, Cognitive Strategy Instruction, and Reading in Adult Literacy. (Online), (www.ncsall.net), accesed 1 Maret 2014.

Davidson, J. E. \& Sternberg, R. J. 1998. Smart Problem Solving: How Metacognition Helps. In D. J. Hacker., J. Dunlosky, A. C. Graesser (Eds.), Metacognition in EducationalTheory and Practice (pp. 4768). Mahweh, NJ: Lawrence Erlbaum Associates.

Desoete, A., Roeyers, H. \& Buysse, A. 2001. Metacognition and Mathematical Problem Solving in Grade 3. Journal of Learning Disabilities; Sep-Oct 2001; 34, 5; Academic Research Library.p 435. (Online), (www.fi.uu.nl), accesed 16 September 2014.

Djamarah, S. B. 2008. Psikologi Belajar. Jakarta: Rineka Cipta

Duffin, J.M. \& Simpson, A.P. 2000. A Search for Understanding. Journal of Mathematical Behavior. 18(4): 415-427.

Efklides, A. 2005. Metacognition and Affect: What Can Metacognitive Experiences Tell Us about the Learning Process? (Online), (www.researchgate.net), accesed 24 Januari 2014.

Flavell, J. 1976. Metacognitive Aspects of Problem Solving. in L. Resnick (Ed),
In the Natrure of Intelligence. (Online), (www.library.edu), accesed 12 Juli 2014.

Goos, M., Galbraith, P. \& Renshaw, P. 2002. Socially mediated metacognition: creating collaborative zones of proximaldevelopment in small group problem solving. Educational Studies in Mathematics, 49, 193-223.

Howard, B.C., McGee, S., Shia, R. \& Hong, N.S. 2000. Metacognitive Self-Regulation and Problem-Solving: Expanding the Theory Base Through Factor Analysis. (Online), (www.cet.edu), accesed 12 September 2014.

Hudojo, H. 1988. Mengajar Belajar Matematika. Jakarta: Departemen Pendidikan dan Kebudayaan.

In'am, A., Sa'ad, N., \& Ghani, S.A. 2012. A Metacognitive Approach to Solving Algebra Problems. International Journal of Independent Research and Studies. University Pendidikan Sultan Idris, Malaysia. (Online), ISSN: 2226-4817; EISSN: 2304-6953 Vol. 1, Number 4, October2012, p162-173,(www.aiars. org/ijirs), accesed 4 Mei 2014.

Livingstone, J.L. 1997. Metacognition: An Overview. (Online), (www.gse.buffalo.edu/fas), accesed 2 Juni 2014.

Kuzle, A. 2011. Patterns of Metacognitive Behavior During Mathematics Problem Solving in a Dynamic Geometry Environment. (Online).Volume 8, Number 1, January 2013, (www.jwilson.coe.uga.edu), accesed 20 September 2014.

Larkin. S. 2000. How Can We Discern Metacognition in Year One Children from Interactions Between Students and Teacher. (Online), (www.tlrp.org), accesed 3 Juli 2014.

Lioe, L.T., Ho Ka Fai \& Hedberg. 2006. Students' Metacognitive Problem Solving Strategies in Solving Open-ended Problems in Pairs. (Online), (www.math.ecnu.edu.cn), accessed3 Februari 2014.

Magiera, M. T. \& Zawojewski, J. S. 2011. Characterizations of Social-Based and Self-Based Contexts Associated with Students' Awareness, Evaluation, and Regulation of Their Thinking During Small-Group Mathematical Modeling. Journal for Research in Mathematics Education. Number 5, Voume 42 November 2011. p. 486-516. 
Mokos, E. \& Kafoussi, S. 2013. Elementary Students' Spontaneous Metacognitive Functions Different Types of Mathematical Problems. Journal Research in Mathematics Education. (Online), volume 2 number 2, June 2013. p 242267. (www.hipatiapress.com), accessed 14 April 2014.

Moleong, L.J. 2008. Metode Penelitian Kualitatif. Bandung: PT Remaja Rosda Karya.

Panaoura, A., Gagatsis, A. \& Dimetriou, A. 2009. An Intervention to the Metacognitive Performance: Self-Regulation In Mathemathics and Mathematical Modeling. Acta Didactica Universitatis Comenianae Mathematics, (Online), Issue 9, 2009, p. 63-79, (www.researchgate. net), accessed 2 Juni 2014.

Polya, G. 1988. How to Solve It, A New Aspect of Mathematical Method. Oxford: Princeton University Press Princeton and Oxford.

Praba, G. J. 2013. Metacognitive Instruction and Cooperative Learning Strategi for Promoting Insightful Learning in Science. International Journal on New Trends in Education and Their Implications. (Online), January 2013 Volume: 4 Issue: 1 Article: 15 ISSN1309-6249.January 2013, (www:ijonte.org), accessed 30 Maret 2014.

Purnomo, D. 2014a. Proses Metakognisi Kalkulus Siswa dalam Pemecahan Masalah. Makalah disampaikan dalam Kegiatan Seminar Nasional Pendidikan Matematika di Universitas Ronggolawe. Tuban, 24 Mei 2014.

Purnomo, D. 2014b. Profil Metakognisi Kalkulus Siswa Kelas3 SekolahDasarpadaPemecahan Masalah Bangun Datar Berdasar Kerja Kelompok. Makalah disampaikan dalam Kegiatan Seminar Nasional tentang Penelitian Pendidikan di Universitas Kanjuruhan Malang, 14 Juni 2014.

Purnomo, D. 2014c. Proses Metakognisi Kalkulus Siswa Sekolah Dasar pada Pemecahan Masalah dalam Kelompok Kecil. Makalah disampaikandalamkegiatanKonferensi Nasional Matematika XII di Institut Teknologi Sepuluh Nopember (ITS). Surabaya, tanggal 11-13 Juni 2014.
Purnomo, D. 2014d. Proses Metakognisi pada Kelompok Kecil Siswa Kelas III Sekolah Dasar dalam Memahami Konsep Bangun Datar. Makalah disampaikan dalam Kegiatan Seminar Nasional Pendidikan Matematika di Universitas Sanata Dharma Jogjakarta, 13 September 2014.

Schoenfeld. 1994. Mathematical Thinking and Problem Solving. New Jersey: School Mathematics. Reston: NCTM

Soedjadi, R. 2000. Nuansa Kurikulum Matematika Sekolah Di Indonesia. Dalam Majalah Ilmiah Himpunan Matematika Indonesia (Prosiding Konferensi Nasional Matematika X ITB, 17-20 Juli 2000

Tan O. S., Parsons, R. D., Hinson, S. L., \& SardoBrown, D. 2003. Educational Psychology a Practitioner-Researcher Approach. Australia: Thomson.

Veenam, M.V.J., Wilhelm, P., \& Beishuize, J. J. 2004. The Relation Between Intellectual and Metacognitive Skills from a Developmental Perspective. (Online), (www.elsevier. com), accessed14 September 2014.

Wellman, H. M. 1985. Origins of Metacognition. In D. L. F. -Pressley, G. E. Mc Kinnon and T. G. Waller (Eds.), Metacognition, Cognition and Human Performance (Volume 1). Orlando, Florida: Academic Press.

Wilson, J. \& Clarke D. 2002. Monitoring Mathematical Metacognition. Paper presented at the Anual Meeting for the American Education Research Assosiation, New Orleeans, LA.

Wilson, J. \& Clarke D. 2004. Towards the Modelling of Mathematical Metacognition. Mathematics Education Research Journal.(Online), 16(2) p. 2548, (www.files.eric.ed.gov), accesed $12 \mathrm{Juli}$ 2014.

Zawojewski, L.R. 2007 Problem-Solving and Modeling. In F. Lester (Ed.), Second Handbook of Research on Mathematics Teaching and Learning (pp. 763-804). Reston, VA: NCTM.

Zechmeister, E.B. \& Neyberg, S.E. 1982. Human Memory: An Introduction to Research and Theory. Monterey, CA: Brok/Cole Publishing Company. 
94 | Dwi Purnomo, Karakteristik Proses Metakognisi Mahasiswa ... 